\title{
A informação arquivística no processo detomada de decisão em organizações universitárias.
}

MORENO, Nádina. Aparecida. A informação arquivística no processo detomada de decisão em organizações universitárias. 2006. $220 \mathrm{f}$. Tese(Doutorado em Ciência da Informação) - Escola de Ciência da Informação,Universidade Federal de Minas Gerais, Belo Horizonte, 2006.

O objetivo desta pesquisa é investigar o papel da informação arquivística no processo de tomada de decisão em universidades públicas. Foi efetuado um estudo de caso, na Universidade Estadual de Londrina, no Paraná, junto a dois conselhos superiores deliberativos: Conselho Universitário e Conselho de Administração. Para tanto, utilizou-se a pesquisa qualitativa, adotando-se a técnica do incidente crítico e da análise documental. Empregou-se a entrevista semi-estruturada cuja análise foi efetuada com respaldo na teoria de Bardin. Analisou-se o percurso de um processo, dentro da instituição, que tivesse sido objeto de deliberação de, no mínimo, dois conselhos superiores, entrevistando-se os atores do processo (responsáveis pelas informações registradas no mencionado processo) e os decisores, por meio e um roteiro semi-estruturado. Constatou-se que, em relação aos elementos que dificultam obter e recuperar a informação, o mais apontado pelos gestores universitários refere-se à fragmentação e à dispersão das informações, na Universidade, realidade decorrente da ausência de uma política de gestão documental. Observou-se, também, que o modelo de decisão colegiada é o mais adotado na Instituição. Identificou-se, tanto na análise documental como nas entrevistas realizadas, que ainformação arquivística é muito utilizada pelos gestores universitários, no contexto de suas ações para a tomada de decisão, independente do modelo de gestão adotado na Universidade Constatou-se, também, que, na literatura da área onde são abordados os assuntos referentes à administração, à informação estratégica e à inteligência competitiva, não se observa qualquer referência à informação arquivística. Entretanto, a informação estratégica apresenta características e peculiaridades da informação arquivística. 